\title{
GLACIERS AND CLIMATE IN SVALBARD: STATISTICAL ANALYSIS AND RECONSTRUCTION OF THE BRØGGERBREEN MASS BALANCE FOR THE LAST 77 YEARS
}

by

\author{
B. Lefauconnier and J.O. Hagen
}

(Norsk Polarinstitutt, P.O. Box 158, N-1330 Oslo Lufthavn, Norway)

\section{ABSTRACT}

The long series of mass-balance data obtained by the Norsk Polarinstitutt on Brøggerbreen for the period 1967-88 has been correlated to climatological parameters from the meteorological station in $\mathrm{Ny}$-Álesund. The best multiple correlation coefficient was obtained between mass balance and positive summer and autumn temperatures combined with winter precipitations, for which $R=0.90$. The regression equation gives a very good agreement between observed and estimated mass balance for Brøggerbreen. A test for 8 years which includes summer long-wave radiation, gives a coefficient of $R=0.98$. Based on the good correlation between temperatures at several stations, we reconstructed summer temperatures in Longyearbyen and Brøggerbreen mass balances for 1912-88. The end of the cold period before 1918 is connected with historical observations of the maximum advance of cirque glaciers. After an increase between 1912 and 1920, summer and autumn temperatures decreased slowly. From 1920 this decay has been of $-0.7^{\circ} \mathrm{C}$. Mass balance has been negative since 1918 , and the total mass lost at Brøggerbreen is $34.35 \mathrm{~m}$ of water equivalent. For the period with available data in Ny-Ålesund (1969-88), a very slight cooling during the ablation period and an increase in winter precipitation has maintained the reduction of the net balance deficit.

\section{INTRODUCTION}

To understand the relationship between glaciers and climate requires two types of analysis: study of physical processes, and comparison of the changes of position of glacier fronts and climatic parameters. Using mass-balance data, Martin (1978) found a good multiple correlation explaining $77 \%$ of the variance between net mass balance of two glaciers in the French Alps and maximum summer temperature, precipitation from October to May and precipitation in June.

In the Kongsf jord area of Svalbard $\left(79^{\circ} \mathrm{N}\right)$, a long record of mass balance (22 years for Brøggerbreen) and location in the immediate vicinity of a climatic station in $\mathrm{Ny}$-Álesund has provided the opportunity to carry out such statistical analysis. Moreover, temperature records from other meteorological stations in Spitsbergen have permitted reconstruction of Brøggerbreen net balance since 1912. Meteorological observations are provided by the Norsk Meteorologisk Institutt.

CORRELATION BETWEEN ANNUAL MASS BALANCE AND CLIMATIC PARAMETERS

Data Winter, summer and annual mass balance from east

TABLE I, VALUES OF PARAMETERS USED IN THE CALCULATIONS. 1: years, 2: net balance, 3,4,5: positive degree days in June, July and August, 6: positive degree days before the first winter snow for September and October together, 7: winter precipitation in $\mathrm{mm}$ of water from October to May, 8 and 9: long-wave radiation from the atmosphere in July and August in kjoules $\mathrm{m}^{-2}$

\begin{tabular}{|c|c|c|c|c|c|c|c|c|c|}
\hline & $\begin{array}{c}1 \\
\text { Year }\end{array}$ & $\begin{array}{c}2 \\
b n\end{array}$ & $\stackrel{3}{d d-06}$ & $\stackrel{4}{d d-07}$ & $\stackrel{5}{d d}-08$ & $\begin{array}{r}6 \\
d d-09 \\
-10\end{array}$ & $\begin{array}{c}7 \\
P w\end{array}$ & $\begin{array}{c}8 \\
L W-07\end{array}$ & $\stackrel{9}{L W-08}$ \\
\hline $\begin{array}{l}1 \\
2\end{array}$ & 1967 & -0.65 & & & & & & & \\
\hline $\begin{array}{l}3 \\
4\end{array}$ & 1969 & -0.93 & $\begin{array}{l}32 \\
45\end{array}$ & 169 & 111 & 72 & & & \\
\hline $\begin{array}{l}4 \\
5\end{array}$ & 1970 & -0.54 & $\begin{array}{l}45 \\
97\end{array}$ & 144 & 122 & 52 & $\begin{array}{l}174 \\
161\end{array}$ & & \\
\hline $\begin{array}{l}5 \\
6\end{array}$ & 1971 & -0.58 & $\begin{array}{r}97 \\
102\end{array}$ & 184 & 121 & 41 & 161 & & \\
\hline $\begin{array}{l}6 \\
7\end{array}$ & 1972 & -0.31 & $\begin{array}{r}102 \\
64\end{array}$ & 154 & 146 & 60 & 284 & & \\
\hline $\begin{array}{l}7 \\
8\end{array}$ & 1973 & -0.08 & $\begin{array}{l}64 \\
77\end{array}$ & 157 & 82 & 31 & 300 & & 86.11 \\
\hline $\begin{array}{l}8 \\
9\end{array}$ & 1974 & -0.92 & $\begin{array}{l}77 \\
58\end{array}$ & 198 & 165 & 38 & $\begin{array}{l}243 \\
273\end{array}$ & $\begin{array}{l}87.61 \\
87.70\end{array}$ & $\begin{array}{l}80.11 \\
77.82\end{array}$ \\
\hline $\begin{array}{r}9 \\
10\end{array}$ & 1975 & $\begin{array}{l}-0.31 \\
-0.45\end{array}$ & $\begin{array}{l}58 \\
94\end{array}$ & $\begin{array}{l}167 \\
174\end{array}$ & $\begin{array}{l}128 \\
128\end{array}$ & 50 & $\begin{array}{l}273 \\
327\end{array}$ & 87.99 & 86.82 \\
\hline 11 & $\begin{array}{l}1976 \\
1977\end{array}$ & $\begin{array}{l}-0.45 \\
-0.11\end{array}$ & $\begin{array}{l}94 \\
49\end{array}$ & $\begin{array}{l}1 / 4 \\
148\end{array}$ & 123 & $\begin{array}{l}20 \\
32\end{array}$ & 254 & 85.60 & 83.05 \\
\hline 12 & 1978 & -0.56 & 79 & 139 & 141 & 24 & 233 & 91.63 & 87.03 \\
\hline 13 & 1979 & -0.71 & 21 & 186 & 141 & 48 & 217 & 85.77 & 82.00 \\
\hline 14 & 1980 & -0.52 & 89 & 141 & 126 & 37 & 276 & & \\
\hline 15 & 1981 & -0.55 & 24 & 141 & 150 & 57 & 209 & & \\
\hline 16 & 1982 & -0.04 & 46 & 123 & 100 & 1 & 154 & & \\
\hline 17 & 1983 & -0.27 & 53 & 165 & 106 & 55 & 232 & & \\
\hline 18 & 1984 & -0.73 & 67 & 176 & 146 & 79 & 273 & & \\
\hline 19 & 1985 & -0.55 & 86 & 202 & 118 & 38 & 305 & & \\
\hline 20 & 1986 & -0.32 & 72 & 184 & 137 & 32 & 349 & 82.72 & 80.96 \\
\hline 21 & 1987 & +0.22 & 48 & 124 & 115 & 4 & 328 & 80.63 & 78.32 \\
\hline 22 & 1988 & -0.52 & 80 & 143 & 155 & 38 & 241 & & \\
\hline
\end{tabular}


Brøggerbreen and central Lovénbreen have been determined respectively since 1967 and 1968 by O. Liestøl and recently by J.O. Hagen. These measurements have been published in the Norsk Polarinstitutt Arbok and in Polar Research. A general study is presented by Hagen and Liestøl (1990, this volume).

Climatic data from the Norsk Meteorologisk Institutt are available since 1969 at the station of $\mathrm{Ny}$-Ảlesund, at $78^{\circ} 5^{\prime} \mathrm{N}$ and $11^{\circ} 56^{\prime} \mathrm{E}$. This station was located on the axis of Brøggerbreen at $42 \mathrm{~m}$ a.s.l. from 1967 to 1974, but in July 1974 it was moved to a new location, $1.6 \mathrm{~km}$ to the east and down to $8 \mathrm{~m}$ a.s.l. Common years of record with other stations are too few to estimate the gap between these two stations. Considering the altitude and the fact that the first station was more influenced by katabatic winds, it is logical to correct temperatures by at least $+0.2^{\circ} \mathrm{C}$. However, neither corrected nor recorded data influence correlation results, so we have used recorded data for our calculations of correlation. To use a precipitation gradient of 5 or $10 \%$ between $\mathrm{Ny}$-Ålesund I and II does not significantly affect the correlation results, so again we have used recorded data.

Records of radiation are available for eight years, 1974-79, 1986, and 1987 (Vinje, 1975-80; personal communication from Hisdal and Finnekảsa). Calculations were made using the STATITCF softward program. All glacial and climatic data used and accepted for our work are shown in Table I. Data used but giving worse statistical results or not accepted as having any real influence are only mentioned in the text.

TABLE II. CORRELATION COEFFICIENTS. "PDD" is the temperature in positive degree days, precipitation is in $\mathrm{mm}$ water equivalent, $L W$ is the long-wave radiation in kjoules $\mathrm{m}^{-2}$. "Temp." in July, August, and September in Longyearbyen is the monthly mean temperature. For relations I, II, III, $P<0.03 \%$; for relation IV, $P<0.3 \%$; for relation $\mathrm{V}, P<0.1 \%$

A. CORRELATION BETWEEN BRØGGERBREEN NET BALANCE AND CLIMATIC PARAMETERS FROM NYÁLESUND:

Number of
years $\quad \begin{aligned} & \text { Correlation } \\ & \text { coefficients }\end{aligned} \quad$ Explanatory variables

Multiple Partial Total

(I)

19

$0.88-0.87 \quad-0.80$

$0.60 \quad 0.25 \quad$ Precipitation from October to May

$19 \quad 0.90$

$\begin{array}{lll}-0.25 & -0.19 & \text { PDD in June } \\ -0.66 & -0.59 & \text { PDD in July } \\ -0.71 & -0.68 & \text { PDD in August } \\ -0.29 & -0.57 & \text { PDD in September }\end{array}$ and October

$0.63 \quad 0.25$ Precipitation from October to May

(III) 20

$\begin{array}{llll}0.79 & -0.61 & -0.71 & \begin{array}{l}\text { PDD in July and } \\ \text { August }\end{array} \\ & -0.52 & -0.63 & \begin{array}{l}\text { PDD in September } \\ \text { and October }\end{array}\end{array}$

(IV) $\quad \begin{array}{lllll}8 & 0.98 & -0.97 & -0.88 & \text { PDD in July and }\end{array}$ August

$\begin{array}{lll}-0.85 & -0.69 & \text { Long-wave radiation }\end{array}$

in July and August

0.740 .57 Precipitation from October to May

B. CORRELATION BETWEEN BRØGGERBREEN NET BALANCE AND TEMPERATURE AT LONGYEARBYEN:

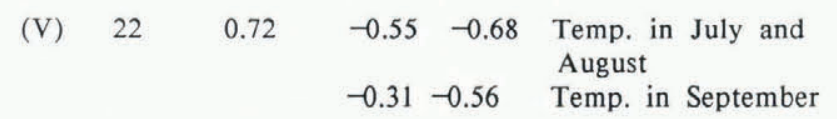

Results

Correlation

The result of multiple correlation between Brøggerbreen mass balance and climatic parameters is presented with several coefficients. This is because it is interesting to determine a useful simple model with the smallest number of parameters possible and a complex model utilizing all influential variables. If we introduce winter precipitation, we lose the first year of climatic record and in this case the series is 1970 to 1988 . Without this parameter it is possible to use a series of 20 years (1969-88).

Coefficients are in Table II. The best multiple correlation coefficient is $R=0.88$, in the simple but useful relation (I) or $R=0.90$ in (II), the more complete. These coefficients explained respectively 77 and $81 \%$ of the variance.

Regression

We used the coefficients from (II). Thus the linear regression equation is:

$$
\begin{aligned}
b n= & -0.0014 \mathrm{~T} 6-0.0053 T 7-0.0067 T 8-0.0023 T(9-10)+ \\
& +0.0019 P(10-5)+1.009
\end{aligned}
$$

and from (IV):

$b n=-0.0065 T(7-8)-0.0181 L W(7-8)+0.0016 P(10-5)+$

+1.009 .

where $b n$ is the estimated net balance, $T 6, T 7, T 8, T(9-10)$, $T(7-8)$ the positive degree day in June, July, August, September and October, July and August, $P(10-5)$ the precipitation from October to May, $L W(7-8)$ the long-wave radiation in July and August.

Figures 1 and 2 show that observed and estimated Brøggerbreen mass balances are fairly close.

\section{Discussion}

Summer temperature

The slightly higher coefficient in (II) of Table II introduces positive degree days separately for June, July and August and together for September and October, and Equation (1) uses for these months significantly different regression coefficients. Months of June, September, and October are influential from time to time: at the end of 1969 , the ablation season was extra long because of positive temperatures and lack of snow in September and October. Liestøl (1970) noticed that the ablation season ended at the beginning of November.

The analysis shows that, for some exceptional years, "positive degree days" for every month from the beginning to the end of the ablation season are the best parameters, but if we want only a useful estimation, the use of just the mean temperature in July plus August and September gives a sufficiently good approximation. Relation (III) in Table II and Figure 1 show that an estimation by summer temperatures alone is probably a sufficiently correct estimation.

\section{Winter precipitation}

Previous work, for the period 1969-85 (Lefauconnier, 1987) gave the best result by taking into account spring precipitation from April and May. This was confirmed by a comparable analysis between mass balance of Vöringbreen and climatic parameters from the meteorological station of Barentsburg, situated on the west coast, $100 \mathrm{~km}$ to the south of $\mathrm{Ny}$-Ålesund (personal communication from L. Troitskiy). For a shorter period of 13 years, 1974-86, the best multiple correlation coefficient $(R=72)$ was between Vöringbreen mass balance and summer temperature from July and August combined with precipitation from April and May.

Spring precipitation keeps a high albedo on the surface at times when solar radiation is the only factor causing melting. We eliminated spring precipitation as parameter for four reasons. First, the total correlation coefficient between mass balance and spring precipitation decreases from the beginning to the end of the period. Secondly, if the parameter is influential, there would be a negative correlation between the spring precipitation and the summer balance, whereas this correlation is close to zero. Thirdly, the multiple correlation with $b n$ is better if the month of 


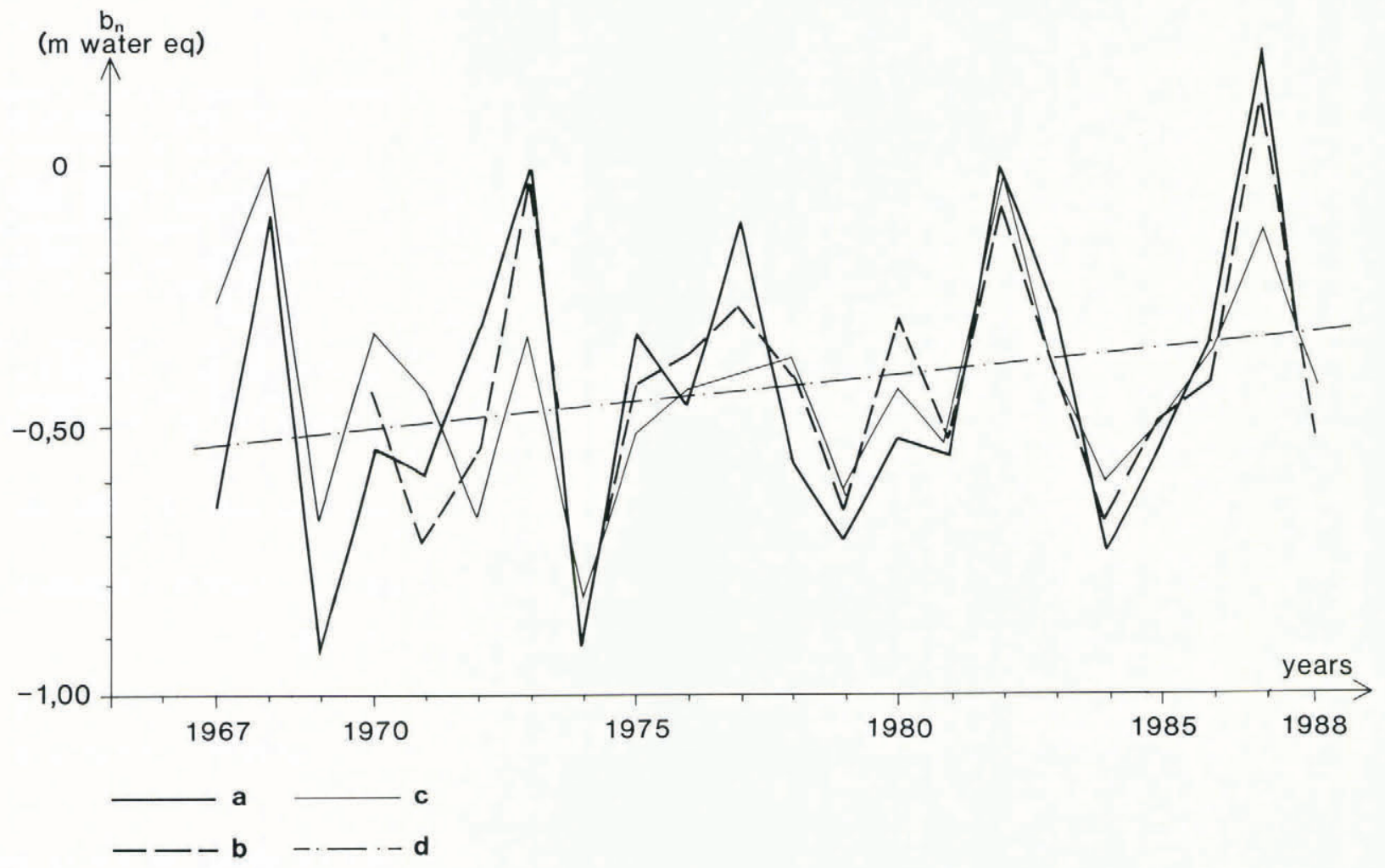

Fig. 1. Brøggerbreen net balance for the period 1967-88 (a) $b n$ observed, (b) $b n$ estimated from summer and autumn temperatures and winter precipitation at $\mathrm{Ny}$-Ảlesund (see Equation (1)), (c) bn estimated from summer and autumn temperatures in Longyearbyen (see Equation (3)), (d) trend of the observed net balance.

March is included in the spring precipitation, which is not logical. Fourthly, in 1988 it was observed that the change in snow cover (temperature and density) did not start before late May.

However, despite this previous result, it appears that winter precipitation has a part in the relation. There is a fairly good correlation between precipitation from October to April with the winter balance $b w$, for which $R=0.70$. This reflects the very close proximity of glacier and meteorological station. Hagen and Liestøl (1990, this volume), show that the change in the Brøggerbreen annual balance for a period of 22 years is well related to the change in the winter balance. Trend analysis (see below) confirms the importance of this winter balance and of the winter precipitation.

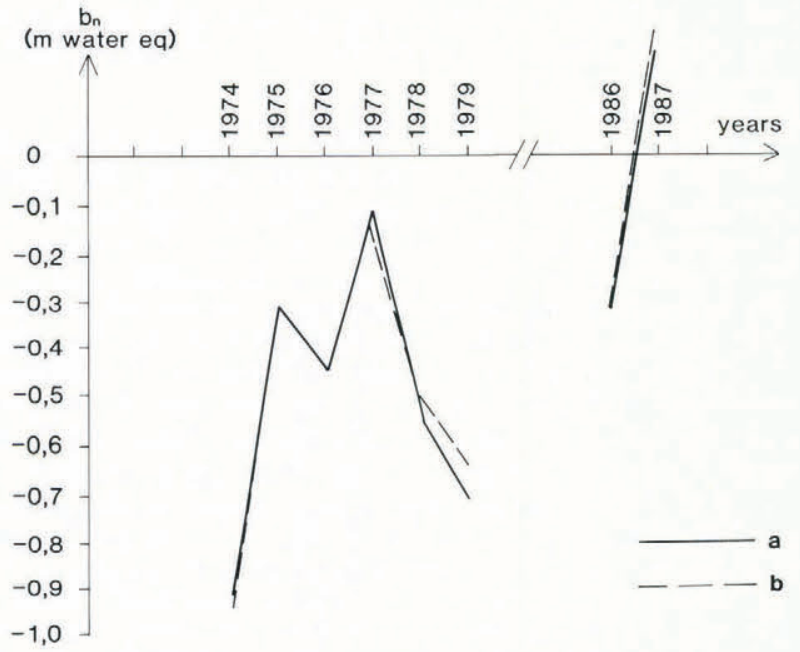

Fig. 2. Eight years of Brøggerbreen net balance (a) bn observed, (b) $b n$ estimated from summer temperatures, summer long-wave radiation and winter precipitation in $\mathrm{Ny}$-Ålesund (see Equation (2)).

\section{Radiation}

In view of the limited number of observations, we have introduced the fewest explanatory variables possible. The best correlation coefficient is obtained with the use of just one more parameter, long-wave radiation from the atmosphere in July and August (V). Introducing June decreased the coefficient and in September data are missing. Introducing the global radiation increased the coefficient by $1 \%$ but using this parameter as the only radiation coefficient decreased considerably the multiple correlation coefficient. We consider two points. First, for a given cloud cover the global radiation increases with the albedo of the surface, i.e. when the effect of the global radiation on the glacier is lower. The daily record shows this very well and confirms a similar analysis by Vinje (1977). Secondly, it is less important than the long-wave radiation, especially in August, for July and August, the total correlation coefficient with $b n$ is low $(R=-0.27$ against $R=-0.69$ for the long-wave radiation). This analysis agrees with Braithwaite and Olesen (1985) who found in West Greenland little relationship between ablation and global radiation and suggested that the best parameter would be long-wave radiation.

\section{BRØGGERBREEN MASS BALANCES SINCE 1912}

\section{Reconstruction for the period 1912-88}

There is a good correlation between the Brøggerbreen annual mass balance and temperature in $\mathrm{Ny}$-Âlesund (Table II), and a similar evolution of summer temperatures at every station in Svalbard, including Bjørnøya and Jan Mayen, is known (Steffensen, 1982). The most complete series of observations are for Isfjord Radio and Longyearbyen situated almost $100 \mathrm{~km}$ from $\mathrm{Ny}$-Ảlesund. We chose to reconstruct temperatures in Longyearbyen. For the period 1976-88 we used data from Ny-Âlesund, because we have a good correlation and also corroboration from the Svalbard Lufthavn record, $5 \mathrm{~km}$ from Longyearbyen. For missing records during the period 1912-56, we used data from Isf jord Radio. Thus we have summer and autumn temperatures in Longyearbyen from 1912 to 1988 (Fig. 3). The multiple coefficient correlation between Brøggerbreen 


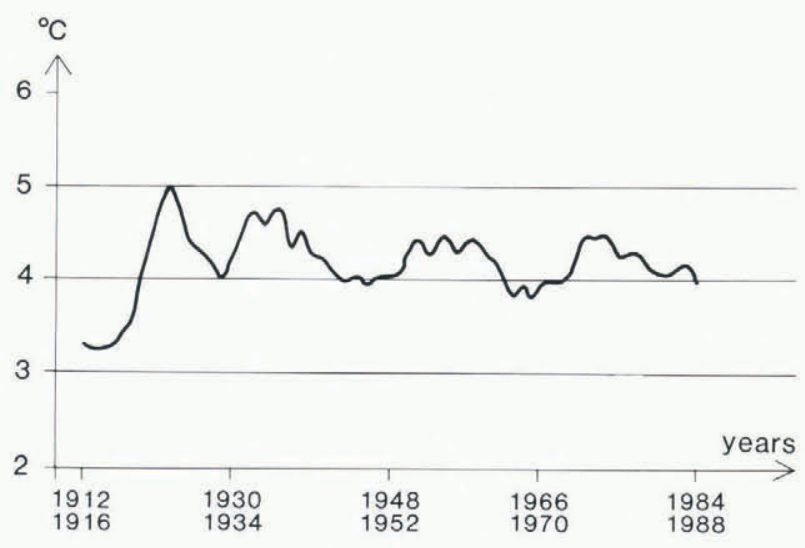

Fig. 3. Five-year running mean temperatures of July, August, and September in Longyearbyen for the period 1912-88. Recorded data for 12 years between 1916 and 1946 and for the period 1957-76. Reconstructed data for other years before 1957 and for the period 1976-88.

mass balance and these temperatures is $R=0.72$ with 22 years of data, explaining $52 \%$ of the variance. The equation of the linear regression is:

$$
b n=-0.35 T(7-8)-0.05 T(9)+1.603
$$

where $b n$ is the estimated mass balance, $T(7-8)$ the mean temperatures in July and August, $T(9)$ the mean temperature in September.

The comparison between observed and estimated mass balances is shown in Figure 1. There are some gaps, year to year, but the observed and estimated mean and cumulative mass balances are equal; the annual average is $-0.43 \mathrm{~m}$ and the total is $-9.53 \mathrm{~m}$ of water equivalent. The standard deviation is $\delta=0.28 \mathrm{~m}$ for observed and only $\delta=0.20 \mathrm{~m}$ for estimated data. Summer temperatures in Longyearbyen explain only half of the annual variation of mass balance but give a good estimation of cumulative values.

There is no complete record of precipitation but some data are available from Isfjord Radio, on the west coast, $100 \mathrm{~km}$ south of $\mathrm{Ny}$-Ảlesund. For 1935-41 the average winter precipitation was $231 \mathrm{~mm}$, whereas in 1956-76 this average was $250 \mathrm{~mm}$, a difference of less than $8 \%$. Thus it is possible that the proposed reconstruction may overvalue the cumulative mass balance, but probably only very slightly.
We present in Figure 4 the evolution of the cumulative net mass balance for Brøggerbreen since 1912. The total mass of ice lost since this date is $34.35 \mathrm{~m}$ of water equivalent, with a mean of $-0.45 \mathrm{~m}$ per year.

Accordance between the estimated balance and historic observations

We have shown that the shrinkage of Brøggerbreen started around 1918. In 1907, Isachsen (1912) observed and took pictures of small cirque glaciers on Brøgger peninsula. $\mathrm{He}$ noticed that east and west Brøggerbreen, east, central and west Lovénbreen and Pedersenbreen were at their maximum for the time. Their fronts were domed, with an associated frontal moraine, and there were no other frontal moraines down-stream. The maximum volume could have occurred a few years later. A picture from 1923 (de Geer, 1930) shows that these glacier fronts were at or very close to their maximum extent. Later, aerial photography from 1936, 1948, 1966, 1969, and 1977 and contemporary observations indicate that the decrease of these glaciers has been continuous.

Thus, it is possible to estimate that, on the west coast of Spitsbergen, cirque glaciers had their maximum extension between 1907 and 1918 and since then have decreased continuously to the present.

Trends

For the period 1912-88

Figure 3 presents a five year running mean of temperatures from July, August and September in Longyearbyen. The trend for the complete period is close to zero, with a change of temperature of $-0.2^{\circ} \mathrm{C}$. Following a sudden warming in 1917-20, corresponding to the end of the Little Ice Age, the temperature has decreased by approximately $-0.7^{\circ} \mathrm{C}$. Figure 3 shows that successive trends are related to the choice of the start of the period. At least we may assume that, from 1920, the evolution of summer temperature shows a slight decrease, which means that the summer balance is less negative and, if we postulate a weak change in winter precipitation, that the annual net balance is also slightly less negative.

Between 1921 and 1988, wastage of Brøggerbreen reduced from $-0.63 \mathrm{~m}$ to $-0.35 \mathrm{~m}$ in water equivalent per year.

For the period with effective measurements (1967-88)

Wastage reduced from $-0.52 \mathrm{~m}$ to $-0.35 \mathrm{~m}$ (Hagen and Liestøl, 1990, this volume), with a change in the winter balance of $+0.16 \mathrm{~m}$ and in the summer balance of $-0.04 \mathrm{~m}$.

During the period of record at $\mathrm{Ny}$-Älesund (1970-88), winter precipitation increased by $61 \mathrm{~mm}$; that is a small amount but an increase of $25 \%$. Summer temperature has

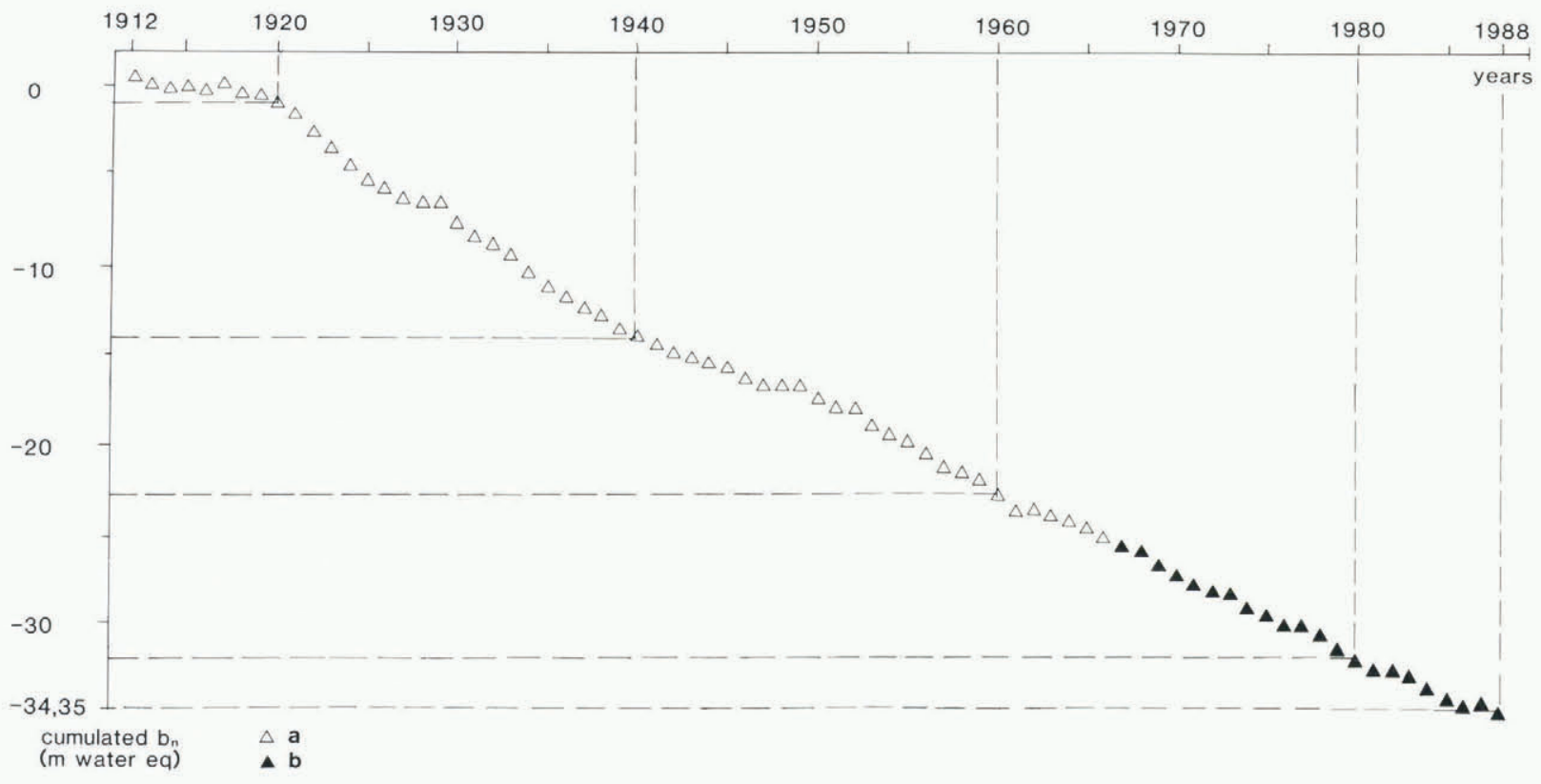

Fig. 4. Cumulative net balance of Brøggerbreen for 1912-88 from temperature in July, August, and September at Longyearbyen (a) estimated net balances, (b) observed net balance. 
decreased, and changes in monthly means were: June, $-0.8^{\circ} \mathrm{C}$; July, $-0.3^{\circ} \mathrm{C}$; August, $0^{\circ} \mathrm{C}$; September, $-0.4^{\circ} \mathrm{C}$. The change in annual temperatures is $-1.2^{\circ} \mathrm{C}$, over the 19 years, a large change, but due in a part to the low temperatures observed in 1988. Nevertheless, the most important regression coefficients are for July and August. The total change for these two months is small and there is a good correlation between the trends of winter precipitation and winter balance and between summer temperature and summer balance.

\section{CONCLUSION}

Brøggerbreen net balance is closely correlated to summer and autumn temperature, summer long-wave radiation and winter precipitation. The net balance has been negative since the end of the Little Ice Age and shows a tendency, from 1920 to the present, to reduce the annual deficit. Trends of summer temperature (slightly negative), and of winter precipitation (clearly positive), show that the present trend is a continued reduction of the deficit. Short variations, as shown in Figure 3, demonstrate that an inverse trend can occur suddenly and prohibits objective extrapolations for the future.

\section{REFERENCES}

Braithwaite, R.J. and O.B. Olesen. 1985. Ice ablation in West Greenland in relation to air temperature and global radiation. Z. Gletscherkd. Glazialgeol., 20, 1984, 155-168.

De Geer, G. 1930. Flygfärder och polarforskning frản
Andrée till nutiden. Jorden runt, 577-608.

Hagen, J.O. and O. Liestøl. 1990. Long term glacier mass balance investigations in Svalbard 1950-88. Ann. Glaciol., 14, 102-106.

Isachsen, G. 1912. Exploration du Nord-Ouest du Spitsberg entreprise sous les auspices de S.A.S. le Prince de Monaco par la Mission Isachsen. Première Partie. Résultats des Campagnes Scientifiques Accomplies sur son Yacht par Albert ler, Prince Souverain de Monaco 40.

Lefauconnier, B. 1987. Unpublished. Fluctuations glaciaires dans le Kongsfjord (Baie du Roi) $79^{\circ} \mathrm{N}$ Spitsberg, Svalbard - analyses et conséquences. (Thèse, Université de Grenoble, 1987.)

Liestøl, O. 1970. Glaciological work in 1969. Nor. Polarinst. Arbok 1969, 116-128.

Martin, S. 1978. Analyse et reconstruction de la série des bilans annuels du Glacier de Sarennes, sa relation avec les fluctuations du niveau de trois glaciers du Massif du Mont-Blanc (Bossons, Argentière, Mer de glace). $Z$. Gletscherkd. Glazialgeol., 13(1/2), 1977, 127-153.

Steffensen, E.L. 1982. The climate at Norwegian Arctic stations. Klima (Norsk Meteorologisk Institutt), 5.

Vinje, T. 1976. Radiation conditions in Spitsbergen in 1974. Nor. Polarinst. Arbok 1974, 205-209.

Vinje, T. 1977a. Radiation conditions in Spitsbergen in 1975. Nor. Polarinst. Arbok 1975, 175-178.

Vinje, T. 1977b. Radiation conditions in Spitsbergen in 1976. Nor. Polarinst. Arbok 1976, 317-318.

Vinje, T. 1978. Radiation conditions in Spitsbergen in 1977. Nor. Polarinst. Arbok 1977, 293-295.

Vinje, T. 1979. Radiation conditions in Spitsbergen in 1978. Nor. Polarinst. Arbok 1978, 67-68.

Vinje, T. 1980. Radiation conditions in Spitsbergen in 1979. Nor. Polarinst. Arbok 1979, 57-58. 